\title{
Study on the Enterprise Financial Management Model under Internet+"
}

\author{
Yan Xu \\ Urban Vocational College of Sichuan, Chengdu, Sichuan, 610101
}

Keywords: "Internet+"; enterprise financial management model; strategy

\begin{abstract}
This paper first analyzes the status quo of the enterprise financial management model, and expounds the urgency of the enterprise financial management model under the background of "Internet+". Finally, it puts forward related strategies to strengthen the enterprise financial management model, which is the inevitable result of social development. It is hoped that the relevant personnel can strengthen the emphasis on the financial management model and promote the long-term development of enterprises.
\end{abstract}

\section{Introduction}

With the rapid development of information technology, "Internet + " came into being. The financial management model is the effective integration of accounting technology and information technology. It has an important influence on the development of enterprises. Unlike large enterprises, the overall size of enterprises is relatively small. Companies need to take advantage of the financial management model to improve their competitiveness.

\section{Current Status of Enterprise Financial Management Model}

Since the reform and opening up, it has provided favorable conditions for the development of enterprises, making these enterprises grow faster and faster, not only promoting the development of the local economy, but also making China's industrial structure more stable. However, there are still some companies that are slow to develop, mainly due to the lack of advanced management methods and low awareness of financial management models, making it difficult for companies to take advantage of the market. Moreover, some business leaders lack long-term goals and do not have the actual needs to establish a financial management model. They believe that this model is not very useful for business development, and only rely on staff and computers to complete the accounting-related work, which will make the business slower to develop. Over time, it will lead companies to face the risk of closure, which is not conducive to the long-term development of the company.

Nowadays, there are several problems in the enterprise financial management model: First, the lack of advanced management concepts. Under normal circumstances, companies in the development process are pursuing the flexibility of the operation, put some of the funds in the enterprise into relatively large areas of return, this will not only enable the company to obtain benefits in the short term, but also make the company have a strong Flexibility [1]. The construction of financial management model requires enterprises to invest a certain cost as a support, in order to improve the level of business management, so that enterprises develop in the direction of modernization, this mode of operation takes a long time to see the return, for the pursuit of rapid return For enterprises, this mode of operation is not much attractive, and it has, to some extent, constrained the expansion of the company's scale. Second, insufficient funds. One of the main reasons for this phenomenon is the limited size of the company, which makes the funds insufficient, and the second is that the company has a certain degree of connection with the use mode in the process of using the funds. In the interest of the project, first try to invest in the project, and then obtain a corresponding return, and then make a large-scale investment in the project. Due to the limited capital of the enterprise, after investing in the project, it is mainly to obtain more economic benefits instead of leaving the project in the hands and improving the competitiveness of the 
enterprise. This results in the existence of a larger corporate financial management model during the construction process. The main reason for difficulties.

\section{Analysis of the Background of Establishing Financial Management Model in Enterprises under the Background of "Internet+"}

In the "Internet + " context, the traditional business model has been unable to meet the actual needs of business development, which requires companies to change the financial management model in order to enable enterprises to occupy a certain position in the market. The first is the need to integrate resources. The continuous development of society requires the continuous development of enterprises. The integration of resources is an inevitable trend of social development. The integration of resources is mainly to integrate decentralized resources into a whole, so that it can play a greater role. At present, there are many enterprises in China, but they lack the competitive strength. Only by integrating the decentralized enterprises into one large enterprise and using the resources in the enterprise in an appropriate position, can the company scale be continuously expanded to meet the needs of social development. However, the traditional accounting work model can not meet the development needs of large-scale enterprises, which requires business leaders to establish a financial management model based on the actual situation, so as to achieve the desired purpose. The second is the need to maintain competitiveness. Institutional management is the main content of modern enterprise competitiveness. Financial management model management can be seen as part of the system management [2]. The management of the system involves many aspects, such as the training of employees and the enterprise system. For enterprises, if they want to have certain advantages in the future competition, they must improve the level of enterprise management. Among them, the financial management model is a very important part. Enhancing the competitiveness of enterprises has an important influence.

\section{The Common Problems in Enterprise Financial Management Model}

Affected by the traditional economic system, the financial managers of some enterprises in our country still have the traditional concept of financial management, which leads to the fact that the company's financial management ideas and actual results can not keep up with the trend of the times, thus reducing the quality of the company's financial management. And some corporate managers believe that the financial department is only a department set up under the government's legal requirements, and the content of financial management is only suitable for daily income and expenditure, which shows that managers pay less attention to corporate financial work. .

In addition, the quality of personnel engaged in corporate financial management at the current stage in China is generally low. According to relevant data, the number of corporate financial personnel owned by our country has reached 500,000 by the end of 2016, but some of these financial personnel have not passed. The relevant accounting qualification examination, and the number of financial personnel with primary accounting qualification certificate, intermediate accounting qualification certificate, and advanced accounting qualification certificate is not large, which represents the current lack of professional level of Chinese corporate financial management personnel, which will largely pull Low efficiency and quality of financial management work [2].

In the financial management of some companies, the phenomenon that the management system is not perfect has emerged, which will lead to problems such as chaotic management of the company's funds, and will affect the authenticity and accuracy of the accounting information of the company. In addition, although some companies have established a relatively complete financial management system, they have not established a special supervision department to supervise the progress of financial management, or there is a phenomenon that the financial management system has not been implemented. The various management systems do not have the effect of mutual influence and mutual restraint. These are all manifestations of the incompleteness of the financial management system of the enterprise.

The financial budget is the main financial work in the process of enterprise development, and the 
accuracy of the financial budget is directly related to the economic benefits of the company. However, as far as the current management situation is concerned, some companies have lower quality of work in terms of financial budget[3]. Some financial management personnel believe that the company's business interests and the sustainability of its development have nothing to do with itself, which results in financial managers failing to maintain their enthusiasm and professionalism in the process of financial management, and may even face problems such as self-defeating law and greed and bribery. In the face of this phenomenon, companies have not formulated a good incentive system. They have not thought about how to improve the current status of financial management but are too dependent on government policies and national macro-control.

At present, China's enterprises are still subject to greater interference by the state and the government, which makes it difficult for companies to establish their own auditing system as other companies do. This affects the enthusiasm of the company's internal staff and financial management personnel for independent work, even if there is specialization in the enterprise. The audit department was set up, but under the condition that the system was not perfect, the audit department could not play its due role. This made the financial management work lose good supervision and restraint. In addition, the external auditing work of the company is also not perfect. The main reason is that the operation has a certain degree of particularity and professionalism. If the staff responsible for the external auditing is not well aware of this industry, it may cause audit problems.

\section{The Related Strategies of Enterprise Financial Management Mode; under the Background of "Internet+"}

Under the "Internet Plus" background, it brings greater challenges to enterprises. If companies want to turn challenges into opportunities, they must change their traditional thinking and increase their competitiveness through the establishment of financial management models to meet the actual needs of corporate development. . At present, China's economy is undergoing a critical period of transition. By slowing down the economic speed, the economic structure is effectively adjusted. To a certain extent, the era of purely economic pursuits of enterprises has ceased to exist, and the future is an intensive society. In order to achieve long-term development, we must improve the overall strength of the company, make effective changes in business concepts and management methods, and apply Internet technology to achieve diversified adjustment of its own management model. This requires that business leaders set long-term goals and do not use short-term economic benefits. The purpose is to establish a financial management model to take long-term consideration of the company and further improve its overall competitiveness.

Enterprises need to increase the utilization rate of funds on the basis of limited funds, so as to bring more economic benefits to enterprises. This requires that corporate leaders use funds rationally and increase product profitability by increasing the added value of products[3] This will not only innovate the traditional business model, but also enable the company to maintain a certain profit. And corporate leaders can use the funds saved to establish financial management models. On the one hand, they can enable companies to have advanced business models, and on the other hand, they can ensure that funds are used in a suitable location. In addition, companies must also strengthen the training of talents. If companies establish financial management models, but lack professional talents, it is also difficult to play the role of financial management models. This requires companies to provide professional training for existing staff. To improve the professional level of the staff and let them master the knowledge of the financial management model, proficiently operate information technology, apply Internet technology, and implement information management for corporate finances. This will not only ensure the reasonable use of corporate funds by staff, but also Corporate development creates greater value.

Improving the professionalism of financial management personnel is a key way to improve the efficiency of financial management in China's industries. To this end, companies need to gradually change the views of managers and financial personnel on financial management work, so that they can clearly define the importance of financial management. Increase the investment and construction of financial management work, and keep up with the current development of financial 
management and the operation of the industry, to constantly adjust their views and opinions [4].

In addition, companies need to continuously improve the overall quality of financial management personnel, can hire professional financial management personnel to the company to give lectures, and professional training of financial management personnel to enable them to understand the current stage of financial management work at the same time, master The new management methods and technologies enable technical personnel to skillfully apply computer technology to achieve network management; major universities should also innovate the knowledge transfer system for accounting students to achieve a good combination of theoretical teaching and practical teaching; financial personnel should also improve The initiative of independent learning, take the initiative to understand the relevant laws and regulations of the industry and accounting expertise, combined with the characteristics of the industry engaged in continuous improvement of their own knowledge system and accounting functions.

In order to ensure the efficiency of corporate financial management and the safety of corporate assets, companies should establish a sound financial management system, and must achieve mutual restraint and mutual cooperation between the systems, in order to provide reference standards for the implementation of financial management. First, companies can establish computerized financial management systems to achieve computerized financial management. While reducing the workload and pressure of staff, they can also improve the efficiency of corporate accounting and capital accounting. It has improved the information and automation level of the enterprise's financial management work [5]. Secondly, enterprises can establish a responsibility system, and on this basis, the company's financial management work will be divided into specific staff, to avoid the phenomenon of one person who has multiple roles, in order to improve the rationality of financial progress. At the same time, it is also possible to investigate the employee's responsibilities in an in-depth manner, thereby improving the enthusiasm of the employees, allowing them to master the knowledge of the financial management model, proficiently operating information technology, and applying Internet technology to achieve information management of the company's financial affairs. Third, companies should establish a financial internal control system to form supervision and constraints on financial management work, promote the development of financial work management of enterprises to a more reasonable and perfect direction, and also provide a system basis for enterprises to fulfill their social responsibilities. It is beneficial to enterprises to increase economic and social benefits at the same time.

The financial statement is a document that directly reflects and summarizes the progress of the company's financial management. Therefore, the company needs to increase the emphasis on the production of financial statements in order to achieve a good disclosure of financial information. The enterprise needs to improve the formulation and formulation of financial statements, specify the content of the statements and accounting items, and conduct a comprehensive analysis of the accounting information in the financial data involved in the statements, and apply electronic information technology to realize the electronic financial statements. It is well established to ensure that the financial statements can provide reference for the following managers to formulate management plans and make decisions [6].

\section{Conclusion}

The financial management model is the inevitable result of social development. Under the "Internet +" background, enterprises must recognize the importance of this model, take the actual situation of the enterprise as a starting point, change the traditional management ideas, and then increase the economic efficiency of the enterprise.

\section{References}

[1] Zeng Yakun. Discussion on the Enterprise Financial Management Mode under the Background of Internet Plus[J]. Value Engineering, 2017, 36(04): 214-217. 
[2] Wang Weijie, Li Liangliang. Discussion on the Enterprise Financial Management Mode Based on "Internet +" [J]. China Management Informatization, 2017, 20(16): 31-32.

[3] Zeng Yakun, Zhang Xianguo. Empirical Research on SaaS Accounting Online Management Model for Enterprise Satisfaction Evaluation [J]. Internal Combustion Engine and Accessories, 2017(19):78-80. 